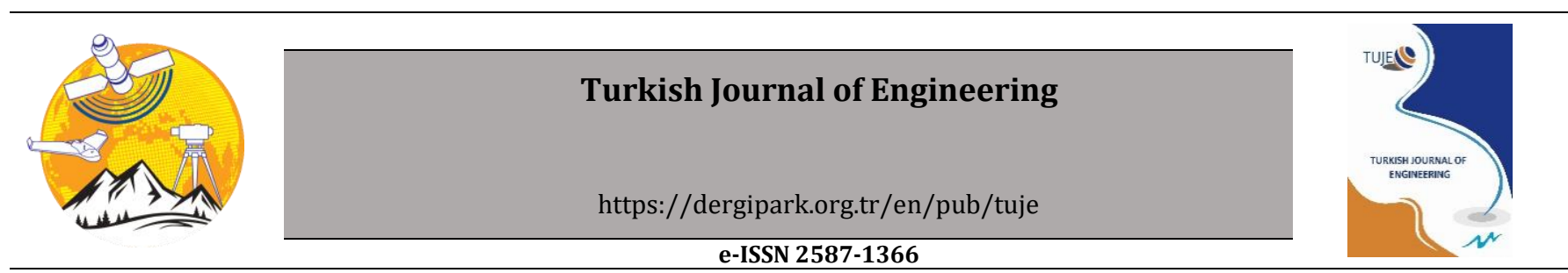

\title{
Strength and behaviour assessment of axially loaded concrete filled steel tubular stub columns
}

\author{
Samoel M. Saleh ${ }^{1}$ (D), Ihsan Al-abboodi ${ }^{* 1}$ (D) \\ ${ }^{1}$ University of Basrah, College of Engineering, Department of Civil Engineering, Basrah, Iraq
}

\author{
Keywords \\ Stub columns \\ CFST \\ 3D Analysis \\ ABAQUS
}

\begin{abstract}
As a result of the excellent performance under different loading conditions, concrete-filled steel tubular (CFST) stub columns are extensively used recently. The current study employs a 3D finite element analysis to assess the response of (CFST) stub columns when subjected to axial compression. The effect of some parameters of concrete and the confining steel tube where numerically investigated. The steel was considered as an elastic perfectly plastic material, whereas a damage plasticity behaviour was adopted for the concrete material. Analysis results suggested that the ultimate strength of concrete increases with the increase of its grade. On the other hand, increasing magnitudes of concrete grade caused a reduction in the ductility of the composite columns. Also, the increase in the steel yields stress, and the steel tube wall thickness contributes to an increase in the columns' ultimate strength. However, they reduce the action of the concrete grade that increases the column's ultimate strength. It was also noted that the ductility that the circular CFST stub columns showed is larger than that for square columns. Thus, the use of square CFST columns with high strength concrete, especially in seismically active areas, should be carefully considered.
\end{abstract}

\section{INTRODUCTION}

The structural advantages and superior response of the concrete filled steel tubular (CFST) columns qualifies them as one of the essential elements in modern structural construction. The interaction of their components contributes to the resistance of applied loads. The confinement pressure of the steel tube makes the concrete core behaves like a material with a triaxial stress state. Meanwhile, the concrete core itself plays a role in eliminating or mitigating the local buckling that may occur in the steel tube. This interaction behaviour means that CFST columns have demonstrated greater strength against axial compression, a higher energy absorption capacity, a better ductility performance, and lower strength degradation than steel hollow sections and reinforced concrete columns if they used separately. Researchers have experimentally and analytically studied the response of of CFST columns under different loading conditions. These studies have provided an extensive database for several design codes in order to develop their design approaches and practices for composite columns, such as those specified in the Eurocode 4, AISC specification, and ACI code. Due to its ability in simulating different structural element, Finite Element Analysis (FEA) can be considered as an effective tool in modelling the CFST columns. However, the accuracy of the FEA is more impacted by the selection of the material modelling for both steel and concrete compared with the other input parameters (Mallesh et al. 2016). Therefore, different material models were developed in previous studies to improve the prediction accuracy of the FEA. Han et al. (2007) suggested a procedure for the numerical modelling of CFST columns subjected to pure torsion. The analysis was conducted by modelling the concrete material as a damaged plasticity model. An elastic perfect plastic model was adopted to define the response of steel material. They developed formulae to predict the ultimate torsional capacity of such composite columns. Deng et al. (2013) theoretically and numerically investigated the flexural behaviour of CFST composite members using FEA. ANSYS software was adopted for a finite element modelling of the problem. Both theoretical and numerical approaches were validated against published experimental studies. They showed that both analysis procedures have the ability to predict the behavioural stages of CFST members, with more accurate results showed by

\footnotetext{
* Corresponding Author
}

(samoel.saleh@uobasrah.edu.iq) ORCID ID 0000 - 0002 - 3046 - 168X

*(ihsan.qasim@uobasrah.edu.iq) ORCID ID 0000 - 0001 - 9256 - 5073
Cite this article

Salih S M \& Al-abboodi I (2021). Strength and behaviour assessment of axially loaded concrete filled steel tubular stub columns. Turkish Journal of Engineering, 5(4); 154-164 
theoretical analysis. Yang et al. (2013) developed a finite element model to simulate ultra-high strength concretefilled steel tubes under compression using ABAQUS software. They validated their model by comparing the simulation results with the data of some experimental tests. Bagherinejad et al. (2015) numerically studied the effect of eccentric loading on the buckling behaviour of rectangular CFST columns using ABAQUS software. Zhao et al. (2018) used experimental and numerical analyses to investigate the behavior of large-scale circular CFST columns under axial compression. They concluded that the horizontal stiffener has a significant constraining effect on the external deformation at the surface of steel tube, whereas the vertical stiffeners may improve the bending resistance and initial stiffness of the column. $\mathrm{Al}-$ Kutti (2018) investigated the possibility of using the Drucker Prager model in the simulation of concrete material for the finite element modelling of concrete CFST members. He suggested empirical formulae to evaluate the material model parameters for confined concrete under compression with a compressive strength that ranged from 25 to $100 \mathrm{MPa}$. Also, in 2018, Ouyang and Kwan (2018) developed a numerical model to study the performance of square CFST columns taking into account the triaxial behaviour and lateral expansion of the concrete core. They found that the increase of corner radius of steel sections improves the post-peak response of columns with square sections. Nguyen et al. (2019) employed a nonlinear finite element analysis to study the effect of tie and slip models in the representation of steel concrete interaction on the flexural resistance of the compact CFST columns. The comparison with some experimental data showed that the tie model provided higher accurate results compared with those predicted by the slip model.

It can be noted from the previous literature review that the interaction in the behaviour of the steel and concrete materials and the configuration of CFST column section may represent the major factors that must be considered in more details with the analysis of such members. However, most of the previous research studied the effect of some parameters in the analysis of CFST columns without considering the variation of other parameters that may lead to significant changes in the strength and behaviour of such structural members. In the present work, a three-dimensional, nonlinear FEA was conducted using ABAQUS software to assess the strength and behaviour of CFST stub columns under axial compression. The effects of the concrete strength (grade of concrete), the steel yield stress, the steel tube wall thickness, and the section shape (circular and square) were examined. This assessment may help to understand the parameters that could play a major role in the axial compressive strength of such composite columns.

\section{FINITE ELEMENT MODELLING AND VERIFICATION}

\subsection{General}

In the current study, ABAQUS software has been employed in the finite element analysis. Eight-noded brick elements (C3D8R) were employed to simulate the structural elements (concrete and steel tube) of the CFST columns. To determine an optimal finite element mesh that gives a low computational time with a relatively accurate solution, mesh convergence studies were investigated. The element size was chosen as $5 \%$ of the overall diameter (circle) or width (square) for column cross-sections. The adopted finite element mesh for both shapes of CFST columns is presented in Fig. 1.

The concept of surface-to-surface contact, presented by Tao et al. (2011), has been used to simulate the interaction between the concrete and steel. As per this method, a coefficient of friction of 0.6 in a direction tangent to the interaction face was adopted in the Coulomb friction model. In addition, a hard contact model was used in the normal direction between the two contact surfaces of steel and concrete. This can prevents the penetration of the interface in compression and permits its separation in tension. According to Tao et al. (2013), the initial local imperfections have no important influence on the response of CFST columns. Therefore, it has been ignored in the modelling procedure.

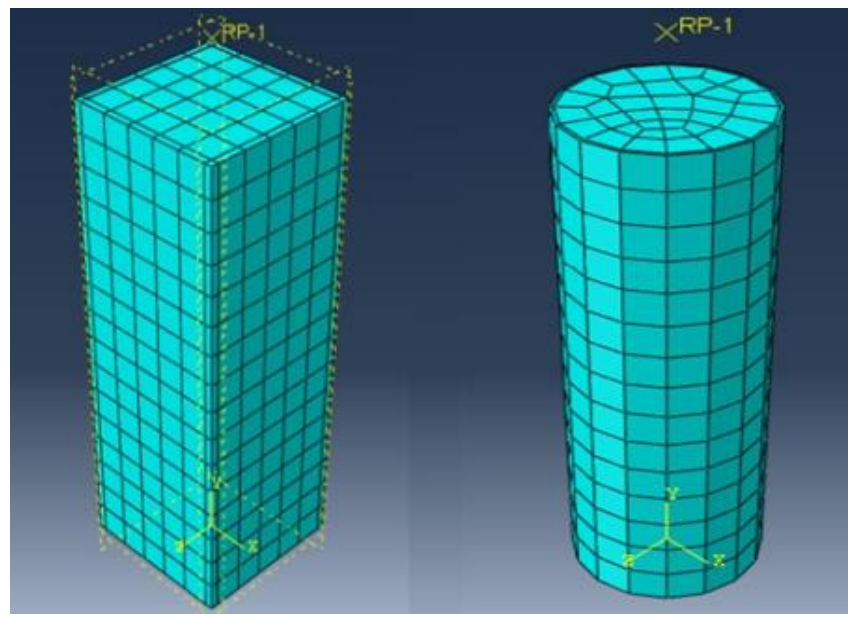

Figure 1. Finite element mesh for the CFST columns used in the analysis

\subsection{Material Modelling}

In the present study, the constitutive behaviour of the steel was considered as an elastic perfectly plastic material, with a modulus of elasticity equals to $200 \mathrm{GPa}$ and a Poisson's ratio of 0.3. Moreover, Von-Mises yield criterion was used to define the steel material yield surface. The damage plasticity model was adopted to model the concrete material.

As the CFST columns loaded axially, the concrete core expanded laterally and confined by the outside steel tube. Due to this confinement, an increase in the strength and ductility of the concrete could be induced. The constitutive stress strain relationship for the concrete and corresponding parameters of the damage plasticity model were considered as suggested by Tao et al. (2013). Moreover, Poisson's ratio was taken as 0.2 , and the value of initial modulus of elasticity was calculated as $4700 \sqrt{f_{c}^{\prime}}$, as recommended by ACI Committee 318.

\subsection{Boundary Conditions and Loading}

Most researchers used end plates when testing the CFST stub columns in order to minimize any influences 
on the end conditions. Therefore, it is suitable to use clamped end conditions for the top and bottom surfaces of the structural member, in which all degrees of freedom will be fixed except the top axial displacement where the load is applied. On the other hand, a displacement control mode was considered to simulate the applied axial compression at the top end of the modelled CFST stub columns.

\subsection{Model Verification}

In order to check the accuracy and efficiency of the adopted procedure, the predicted behaviour and ultimate compressive strengths were compared with some previous experimental data. The adopted experimental tests specimens were chosen with various dimensions and material properties to cover a wide range of case studies, which have been investigated by different researchers. The dimensions, material properties and values of the predicted ultimate compressive strength $\left(\mathrm{N}_{\mathrm{up}}\right)$ and the experimental test strength $\left(\mathrm{N}_{\mathrm{ue}}\right)$ of the selected specimens for verification are given in Tables 1 and 2 . It can be observed that the predicted outputs showed a good agreement with the test results, where mean values of 1.008 and 1.035 for the ratio $\left(\mathrm{N}_{\mathrm{ue}} / \mathrm{N}_{\mathrm{up}}\right)$ were obtained with standard deviation values of 0.071 and 0.036 for specimens with square and circular cross-sections, respectively. Moreover, Fig. 2 and 3 show a comparison between the numerically predicted and experimentally measured axial load - axial shortening profiles for the analysed members.

\section{RESULTS AND DISCUSSION}

The verified nonlinear finite element model was used to carry out a parametric study aims to assess the performance of stub columns under different conditions. A total of eighty columns, equally divided into two categories (i.e. square and circular sections), were analyzed under axial compression. The concrete grade $\left(f_{c}^{\prime}\right)$, the steel yield stress $\left(f_{\mathrm{y}}\right)$, the steel tube wall thickness $(\mathrm{t})$, and the section shape (circular and square) were considered the main parameters. All columns were chosen with the same diameter or width (D) (at $125 \mathrm{~mm}$ ) and with two values of (D/t) ratios (namely 50 and 25). To avoid impacting the end conditions and overall buckling, the length of the analyzed stub columns (L) was chosen as 3D. A summary of the CFST stub columns' details is presented in Tables 3 and 4, whereas the resulting axial load versus the axial shortening relationships are shown in Figs. 4 and 5.

\subsection{Strength Assessment}

The strength and behaviour of concrete core are largely affected by its grade value. Therefore, five grades of concrete, ranging from 25 to $85 \mathrm{MPa}$, were considered to cover the behaviour of such structural members with normal and high strength concretes. It can be seen from Table 3 that the ultimate capacity of columns increases as the concrete compressive strength increases. However, the action of this parameter may be reduced with the variation in other parameters. It was noted that, when the concrete grade increased from 25 to $85 \mathrm{MPa}$ for a circular CSFT column, where a $\mathrm{D} / \mathrm{t}$ ratio of 50 and a steel yield stress of $275 \mathrm{MPa}$, a double value of the column's ultimate capacity has been obtained. Moreover, for a column with the same properties, excepting the steel yield stress of $500 \mathrm{MPa}$, the ultimate strength was increased by about $72 \%$. On the other hand, the increase in ultimate strength along with the increase in concrete grade reduced by $20 \%$ when the $\mathrm{D} / \mathrm{t}$ ratio changed from 50 to 25 .

Four values of steel yield stresses of 275, 350, 425, and $500 \mathrm{MPa}$ were examined to assess their influence on the ultimate capacity of the considered CFST columns. It was noted that the ultimate capacity of the circular columns with a D/t ratio of 50 and a concrete grade of 25 $\mathrm{MPa}$ increased by about $42 \%$ when the value of steel yield stress increased from 275 to $500 \mathrm{MPa}$. However, the increasing percentage was only $20 \%$ when the concrete grade value is $85 \mathrm{MPa}$. Whereas, with the change of $(\mathrm{D} / \mathrm{t})$ ratio from 50 to 25 and the same concrete grade of $25 \mathrm{MPa}$ is adopted, the ultimate capacity of the analyzed circular columns increased by $46 \%$ and $57 \%$ with steel yield stress values of $275 \mathrm{MPa}$ and $500 \mathrm{MPa}$, respectively. The variation in the columns' strengths with respect to the considered parameters is presented in Table 4 for those CFST columns with square sections. It can be noticed that the effect of each individual parameter is slightly more in the square than that in the circular columns.

To consider the influence of the shape of CFST column cross section on its ultimate capacity, a strength index is adopted to verify the column section strength as $S I=$ $N_{u p} / N_{u o}$, where $N_{u o}=A_{s} f_{y}+0.85 A_{c} f_{c}^{\prime}$, as determined by the ACI code for the evaluation of sectional capacity of such composite columns, $A_{s}$ and $A_{c}$ are the cross sectional areas of steel and concrete, respectively.

The strength index (SI) is calculated for each individual column, and the results are shown in Tables 3 and 4. Numerical results showed, in general, that SI values for columns with circular section is considerably greater than that for the columns with square sections. In addition, the strength index decreased with the increased concrete grade for circular columns, but increased for square columns. This may be related to the interaction between the concrete core and the surrounding steel tube, which is more efficient in circular columns than in square columns. On the other hand, there is no significant change in the effect of the column shape on the strength index with the change of steel yield stress or steel tube thickness.

\subsection{Behaviour Assessment}

As can be seen in Figs. 4 and 5, the axial load versus the axial shortening relationships were generally similar in shape until the ultimate load is reached. After that, a difference can be noticed due to the effect of the considered parameters. Nevertheless, in spite of the increase in the steel yield stress, the ductility of the CFST columns reduced with the increase in concrete grade. This is agreed with the engineering expectation since the ductility of concrete reduces with the increase in its strength. On the other hand, it can be clearly noted that the reduction in the values of $\mathrm{D} / \mathrm{t}$ ratio caused an increase 
in the ductility of the stub columns. This is mainly due to the increased in concrete confinement provided by the steel tube.

By comparing Figs. 4 and 5, it can be observed that circular columns are more ductile than the square, where the post peak curves of square columns are steeper than those obtained in the circular columns. This may be attributed to the property of the circular shape for the steel tube, which could produce more efficient confinement and then more ductile behaviour to the concrete core than the square steel tubes.

\section{CONCLUSIONS}

The study adopted a three-dimensional, nonlinear finite element analysis using ABAQUS software to assess the response of CFST stub columns subjected to axial compression. The influence of a number of parameters that could affect the performance of this kind of structural members were investigated. These parameters include the grade of concrete, the steel yield stress, the steel tube wall thickness, and the shape of the column cross-section (circular or square). A total of eighty stub columns divided into two groups depending on their cross-sectional shape were analyzed. Based on the results of the parametric study, a number of conclusions can be drawn:

1.The increase of concrete grade leads to an increase in the ultimate strength of CFST stub columns. On the other hand, a reduction in the ductility has been observed when concrete grade increased.

2.The changes in steel yield stress and $\mathrm{D} / \mathrm{t}$ ratio have caused a significant influence on the ultimate strength and ductility of columns, in which an increase in their values was observed. The effect of these two parameters may reduce with the increase in concrete grade.

3.The composite interaction of concrete in the presence of the surrounding steel tube plays an important role in determining the strength index, SI, values. The effect of this interaction is more pronounced when circular sections are adopted.

4.CFST columns with circular columns showed higher ductility than that obtained in the case of square section.

5.The ductility of circular CFST stub columns is higher than that of square CFST columns. Thus, the use of square CFST columns with high strength concretes should be carefully considered, especially inseismically active areas.

Table 1. Test data for Square CFST stub columns

\begin{tabular}{cccccccccccc}
\hline \multirow{2}{*}{ No } & $\begin{array}{c}\text { Specimen } \\
\text { Label }\end{array}$ & \multicolumn{2}{c}{ Dimensions $(\mathrm{mm})$} & $\mathrm{t}$ & $\mathrm{L}$ & $\begin{array}{c}f_{c}^{\prime} \\
(\mathrm{MPa})\end{array}$ & $\begin{array}{c}\mathrm{f}_{\mathrm{y}} \\
(\mathrm{MPa})\end{array}$ & $\mathrm{N}_{\text {up }}(\mathrm{kN})$ & $\mathrm{N}_{\text {ue }}(\mathrm{kN})$ & $\mathrm{N}_{\text {ue }} / \mathrm{N}_{\text {up }}$ & Test Source \\
\hline 1 & A1 & 120 & 5.80 & 360 & 83.0 & 300.0 & 1744 & 1697 & 0.973 & $\begin{array}{c}\text { Liu and Gho } \\
(2005)\end{array}$ \\
2 & RC2-1 & 120 & 2.86 & 360 & 50.8 & 228.0 & 968 & 992 & 1.025 & Han (2002) \\
3 & UCFT25 & 250 & 2.50 & 750 & 50.1 & 234.3 & 3390 & 3230 & 0.953 & Tao et al. (2005) \\
4 & R7-1 & 106 & 4.00 & 320 & 89.0 & 495.0 & 1662 & 1749 & 1.052 & Liu (2005) \\
5 & SU-040 & 200 & 5.00 & 600 & 27.2 & 265.8 & 2043 & 2312 & 1.132 & Huang et al. (2002) \\
6 & NS1 & 186 & 3.00 & 540 & 32.0 & 300.0 & 1699 & 1555 & 0.915 & Uy (2000) \\
\hline
\end{tabular}

Table 2. Test data for Circular CFST stub columns

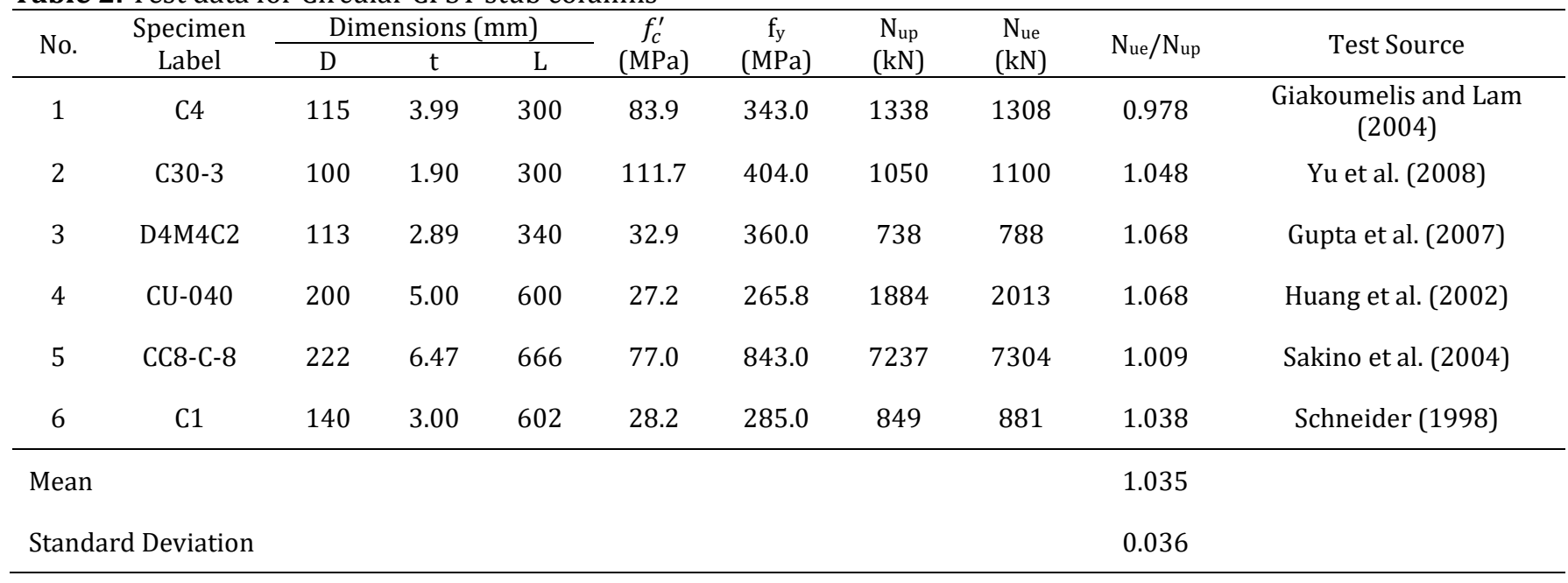



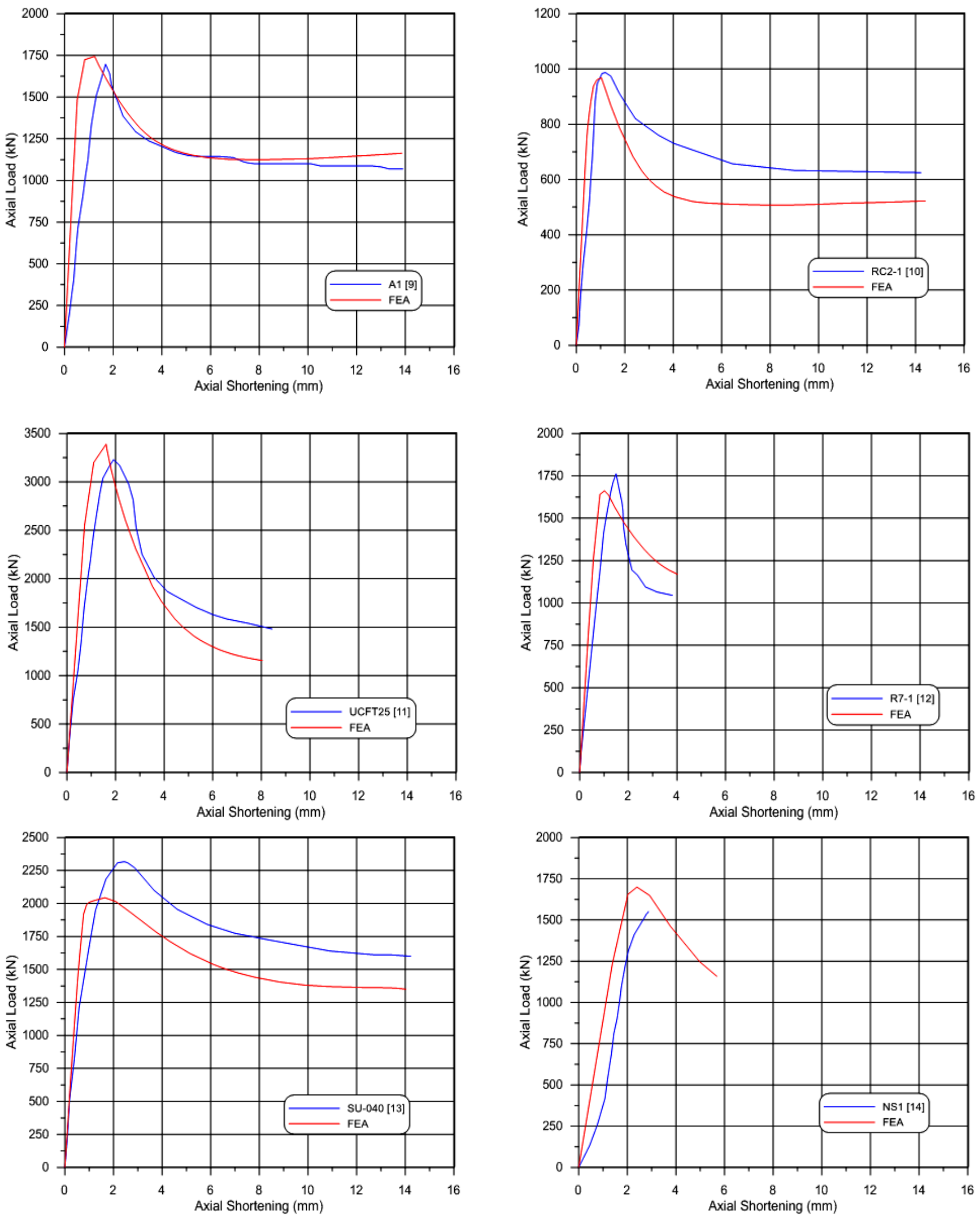

Figure 2. Predicted and measured axial load-axial shortening profiles for square CFST columns 

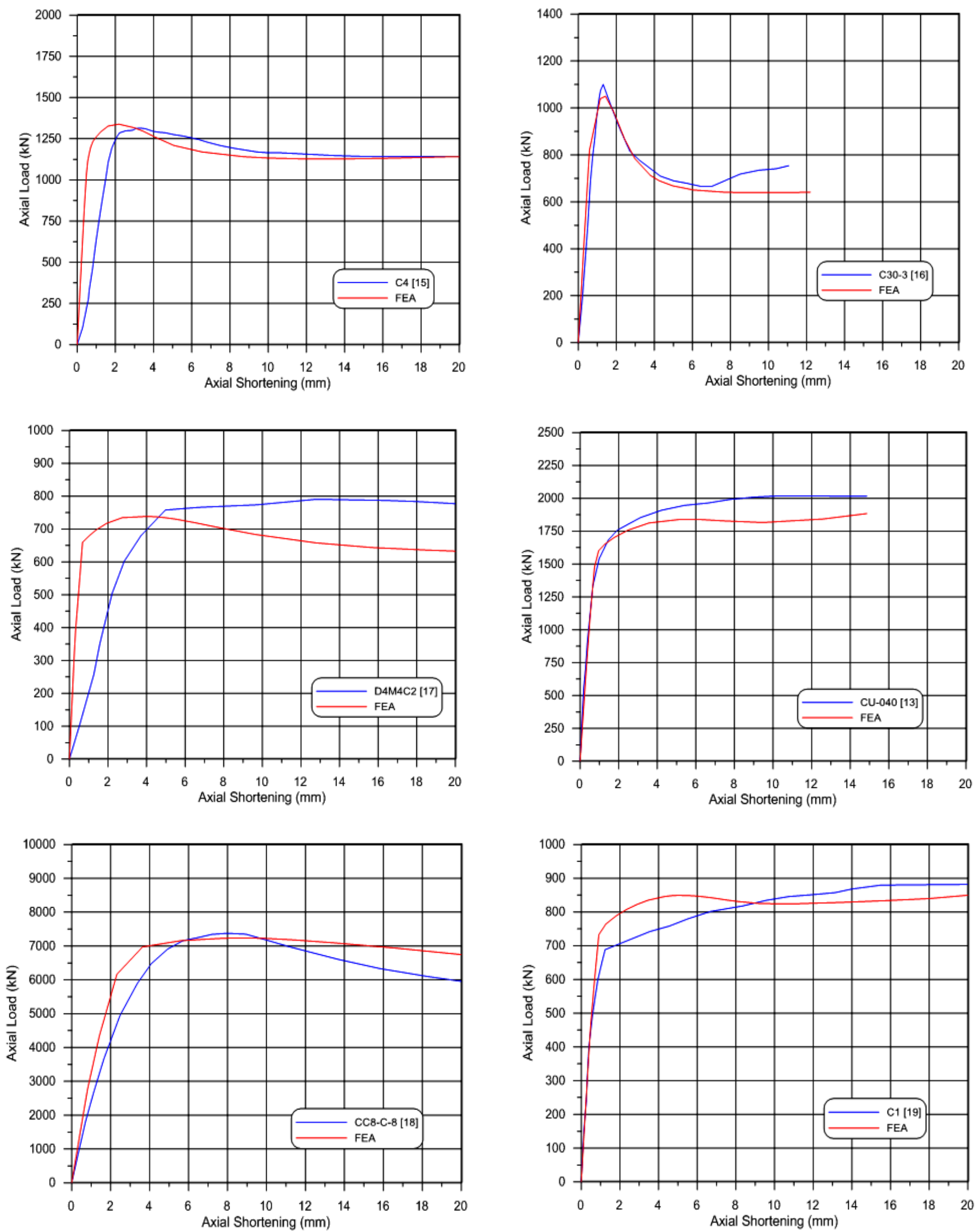

Figure 3. Predicted and measured axial load-axial shortening profiles for Circular CFST columns 
Table 3. Details of analyzed circular CFST stub columns

\begin{tabular}{|c|c|c|c|c|c|c|}
\hline No & $\mathrm{D} / \mathrm{t}$ & $\mathrm{fy}_{\mathrm{y}}(\mathrm{MPa})$ & $f_{c}^{\prime}(\mathrm{MPa})$ & $\mathrm{N}_{\text {up }}(\mathrm{kN})$ & $\mathrm{Nuo}_{\mathrm{u}}(\mathrm{kN})$ & SI \\
\hline 1 & & & 25 & 623 & 505 & 1.234 \\
\hline 2 & & & 40 & 786 & 649 & 1.211 \\
\hline 3 & 50 & 275 & 55 & 948 & 793 & 1.195 \\
\hline 4 & & & 70 & 1105 & 938 & 1.178 \\
\hline 5 & & & 85 & 1271 & 1082 & 1.175 \\
\hline 6 & & & 25 & 713 & 577 & 1.235 \\
\hline 7 & & & 40 & 876 & 721 & 1.215 \\
\hline 8 & 50 & 350 & 55 & 1031 & 865 & 1.191 \\
\hline 9 & & & 70 & 1205 & 1010 & 1.194 \\
\hline 10 & & & 85 & 1371 & 1154 & 1.188 \\
\hline 11 & & & 25 & 800 & 649 & 1.232 \\
\hline 12 & & & 40 & 970 & 793 & 1.222 \\
\hline 13 & 50 & 425 & 55 & 1118 & 938 & 1.192 \\
\hline 14 & & & 70 & 1275 & 1082 & 1.179 \\
\hline 15 & & & 85 & 1449 & 1226 & 1.182 \\
\hline 16 & & & 25 & 887 & 721 & 1.229 \\
\hline 17 & & & 40 & 1059 & 866 & 1.223 \\
\hline 18 & 50 & 500 & 55 & 1221 & 1010 & 1.209 \\
\hline 19 & & & 70 & 1368 & 1154 & 1.185 \\
\hline 20 & & & 85 & 1523 & 1298 & 1.173 \\
\hline 21 & & & 25 & 911 & 739 & 1.233 \\
\hline 22 & & & 40 & 1072 & 872 & 1.230 \\
\hline 23 & 25 & 275 & 55 & 1222 & 1004 & 1.217 \\
\hline 24 & & & 70 & 1363 & 1136 & 1.199 \\
\hline 25 & & & 85 & 1488 & 1269 & 1.173 \\
\hline 26 & & & 25 & 1073 & 880 & 1.219 \\
\hline 27 & & & 40 & 1237 & 1013 & 1.221 \\
\hline 28 & 25 & 350 & 55 & 1393 & 1145 & 1.216 \\
\hline 29 & & & 70 & 1538 & 1278 & 1.204 \\
\hline 30 & & & 85 & 1671 & 1410 & 1.185 \\
\hline 31 & & & 25 & 1235 & 1022 & 1.208 \\
\hline 32 & & & 40 & 1404 & 1154 & 1.216 \\
\hline 33 & 25 & 425 & 55 & 1565 & 1287 & 1.216 \\
\hline 34 & & & 70 & 1709 & 1419 & 1.204 \\
\hline 35 & & & 85 & 1850 & 1552 & 1.192 \\
\hline 36 & & & 25 & 1391 & 1163 & 1.196 \\
\hline 37 & & & 40 & 1568 & 1296 & 1.210 \\
\hline 38 & 25 & 500 & 55 & 1729 & 1428 & 1.211 \\
\hline 39 & & & 70 & 1877 & 1560 & 1.203 \\
\hline 40 & & & 85 & 2024 & 1693 & 1.195 \\
\hline
\end{tabular}


Table 4. Details of analyzed square CFST stub columns

\begin{tabular}{|c|c|c|c|c|c|c|}
\hline No. & $\mathrm{D} / \mathrm{t}$ & $\mathrm{f}_{\mathrm{y}}(\mathrm{MPa})$ & $f_{c}^{\prime}(\mathrm{MPa})$ & $\mathrm{N}_{\text {up }}(\mathrm{kN})$ & $\mathrm{Nuo}_{\mathrm{uN}}$ ) & SI \\
\hline 1 & & & 25 & 705 & 643 & 1.097 \\
\hline 2 & & & 40 & 912 & 826 & 1.104 \\
\hline 3 & 50 & 275 & 55 & 1115 & 1010 & 1.104 \\
\hline 4 & & & 70 & 1333 & 1194 & 1.117 \\
\hline 5 & & & 85 & 1538 & 1377 & 1.117 \\
\hline 6 & & & 25 & 804 & 735 & 1.095 \\
\hline 7 & & & 40 & 1006 & 918 & 1.095 \\
\hline 8 & 50 & 350 & 55 & 1211 & 1102 & 1.099 \\
\hline 9 & & & 70 & 1433 & 1286 & 1.114 \\
\hline 10 & & & 85 & 1635 & 1469 & 1.113 \\
\hline 11 & & & 25 & 896 & 827 & 1.084 \\
\hline 12 & & & 40 & 1100 & 1010 & 1.088 \\
\hline 13 & 50 & 425 & 55 & 1320 & 1194 & 1.106 \\
\hline 14 & & & 70 & 1526 & 1377 & 1.108 \\
\hline 15 & & & 85 & 1731 & 1561 & 1.109 \\
\hline 16 & & & 25 & 994 & 919 & 1.082 \\
\hline 17 & & & 40 & 1204 & 1102 & 1.093 \\
\hline 18 & 50 & 500 & 55 & 1414 & 1286 & 1.100 \\
\hline 19 & & & 70 & 1627 & 1469 & 1.107 \\
\hline 20 & & & 85 & 1836 & 1653 & 1.111 \\
\hline 21 & & & 25 & 1008 & 941 & 1.071 \\
\hline 22 & & & 40 & 1202 & 1110 & 1.083 \\
\hline 23 & 25 & 275 & 55 & 1391 & 1278 & 1.088 \\
\hline 24 & & & 70 & 1586 & 1447 & 1.096 \\
\hline 25 & & & 85 & 1768 & 1616 & 1.094 \\
\hline 26 & & & 25 & 1193 & 1121 & 1.064 \\
\hline 27 & & & 40 & 1389 & 1290 & 1.077 \\
\hline 28 & 25 & 350 & 55 & 1574 & 1458 & 1.079 \\
\hline 29 & & & 70 & 1767 & 1627 & 1.086 \\
\hline 30 & & & 85 & 1962 & 1796 & 1.093 \\
\hline 31 & & & 25 & 1376 & 1301 & 1.057 \\
\hline 32 & & & 40 & 1571 & 1470 & 1.069 \\
\hline 33 & 25 & 425 & 55 & 1764 & 1638 & 1.076 \\
\hline 34 & & & 70 & 1953 & 1807 & 1.081 \\
\hline 35 & & & 85 & 2140 & 1976 & 1.083 \\
\hline 36 & & & 25 & 1557 & 1481 & 1.051 \\
\hline 37 & & & 40 & 1746 & 1650 & 1.058 \\
\hline 38 & 25 & 500 & 55 & 1941 & 1818 & 1.068 \\
\hline 39 & & & 70 & 2138 & 1987 & 1.076 \\
\hline 40 & & & 85 & 2327 & 2156 & 1.079 \\
\hline
\end{tabular}



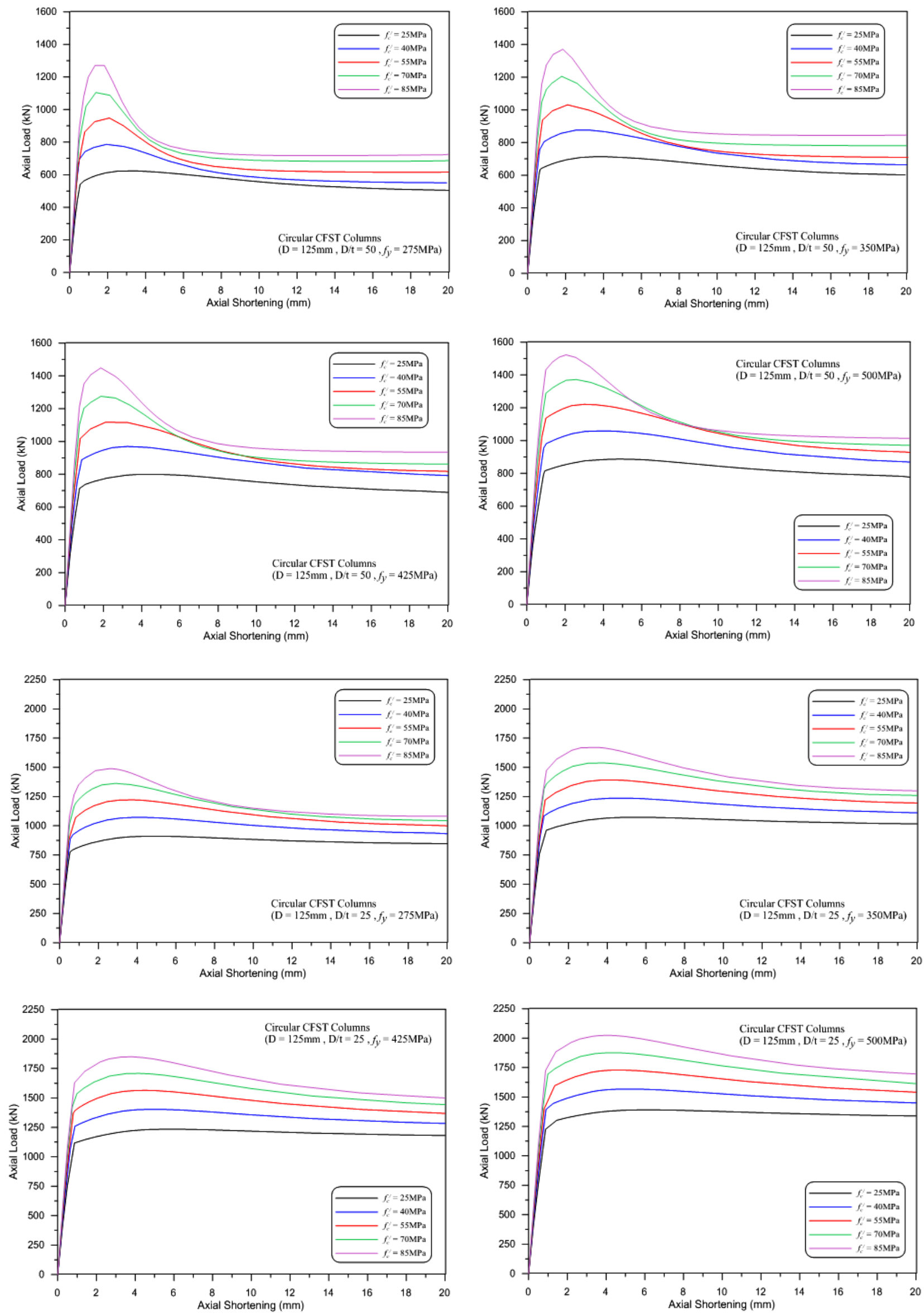

Figure 4. Axial load - axial shortening relationships for analyzed circular CFST Stub columns 

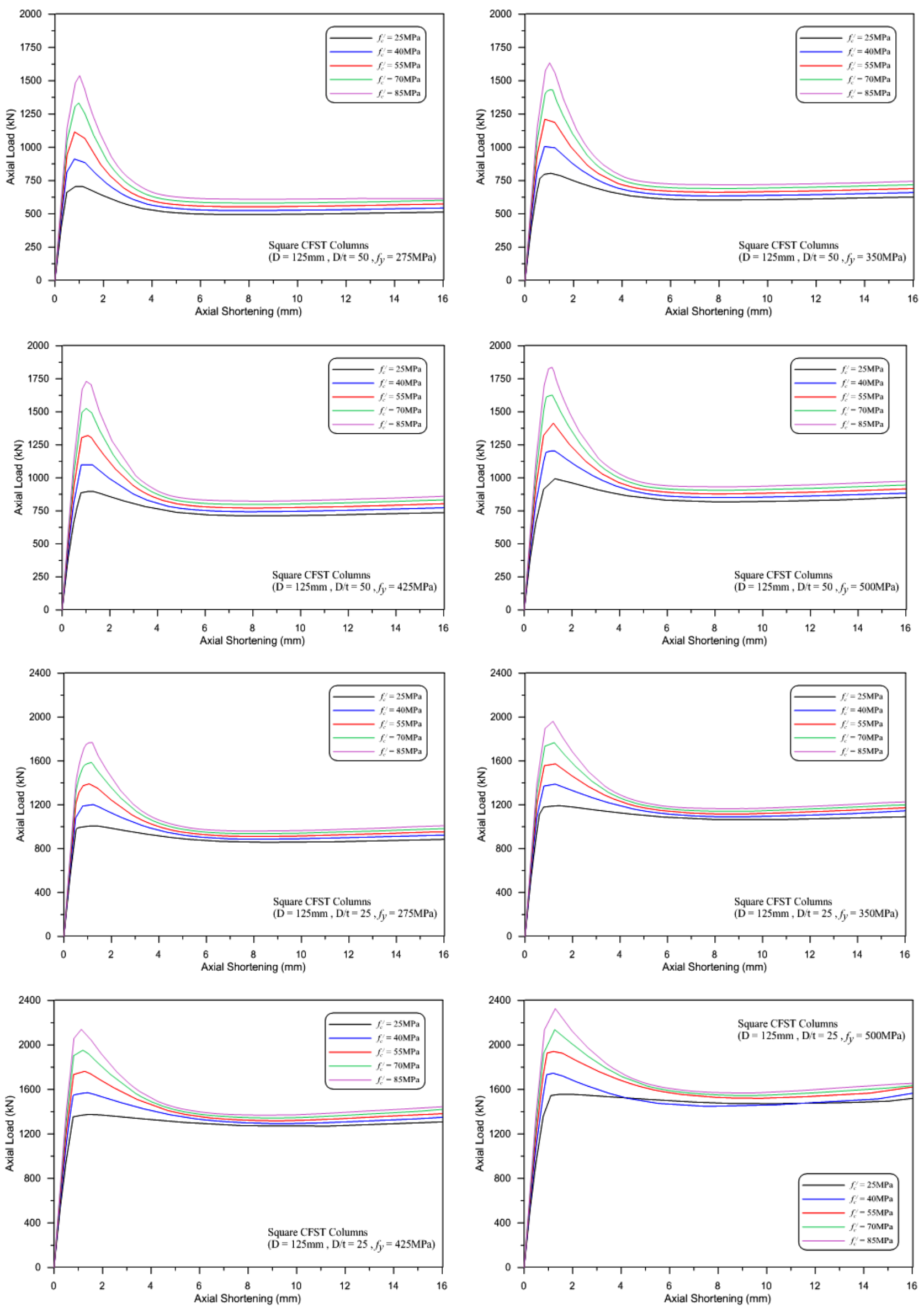

Figure 5. Axial load - axial shortening relationships for analyzed square CFST Stub columns 


\section{REFERENCES}

ABAQUS (2011). Abaqus Theory Manual. ABAQUS version 6.11. Dassault Systèmes Simulia Corp, USA.

ACI Committee (2014). Building code requirements for structural concrete (ACI 318-14) and commentary (ACI 318R-14). American Concrete Institute, Farmington Hills (MI), Detroit, USA.

Al-Kutti W A (2018). Parameters estimation of DruckerPrager plasticity criteria for steel confined circular concrete columns in compression. MATEC Web of Conferences, $\quad 149, \quad 01048 . \quad$ DOI: 10.1051/matecconf/201814901048

Bagherinejad K, Hosseinpour E \& Hosseini S H (2015). Evaluation of rectangular concrete filled steel hollow section beam-columns. Journal of Asian Scientific Research, 5(1), 46-59. DOI: 10.18488/journal.2/2015.5.1/2.1.46.59

Deng Y, Norton T R \& Tuan C Y (2013). Numerical analysis of concrete filled circular steel tubes. Structures and Buildings, 166(1), 3-14. DOI: 10.1680/stbu.11.00001

Giakoumelis G \& Lam D (2004). Axial capacity of circular concrete-filled tube columns. Journal of Constructional Steel Research, 60(7), 1049-1068. DOI: $10.1016 / j . j c s r .2003 .10 .001$

Gupta P K, Sarda S M \& Kumar M S (2007). Experimental and computational study of concrete filled steel tubular columns under axial loads. Journal of Constructional Steel Research, 63(2), 182-193. DOI: 10.1016/j.jcsr.2006.04.004

Han L H (2002). Tests on stub columns of concrete-filled RHS sections. Journal of Constructional Steel Research, 58(3), 353-372. DOI: 10.1016/S0143974X(01)00059-1

Han L H, Yao G H \& Tao Z (2007). Performance of concrete-filled thin-walled steel tubes under pure torsion. Thin-Walled Structures, 45(1), 24-36. DOI: 10.1016/j.tws.2007.01.008

Huang C S, Yeh Y K, Liu G Y, Hu H T, Tsai K C, Weng Y T, Wang S H \& Wu M H (2002). Axial load behavior of stiffened concrete-filled steel columns. Journal of Structural Engineering, 128(9), 1222-1230. DOI: 10.1061/(ASCE)0733-9445(2002)128:9(1222)

Liu D \& Gho W M (2005). Axial load behavior of highstrength rectangular concrete-filled steel tubular stub columns. Thin-Walled Structures, 43(8), 1131-1142. DOI: $10.1016 /$ j.tws.2005.03.007

Liu D (2005). Tests on high-strength rectangular concrete-filled steel hollow section stub columns. Journal of Constructional Steel Research, 61(7), 902911. DOI: $10.1016 / j . j c s r .2005 .01 .001$

Mallesh M, Asif M \& Sreyas G G (2016). Nonlinear analysis of concrete filled stainless steel tubular column.
International Research Journal of Engineering and Technology, 3(8), 1108-1111.

Nguyen D H, Hong W K, Ko H J \& Kim S K (2019). Finite element model for the interface between steel and concrete of CFST (concrete-filled steel tube). Engineering Structures, 185, 141-158. DOI: 10.1016/j.engstruct.2019.01.068

Ouyang Y \& Kwan A K H (2018). Finite element analysis of square concrete-filled steel tube (CFST) columns under axial compressive load. Engineering Structures, 156, 443-459. DOI: 10.1016/j.engstruct.2017.11.055

Sakino K, Nakahara H, Morino S \& Nishiyama I (2004). Behavior of Centrally loaded concrete filled steel tube short columns. Journal of Structural Engineering, 130(2), 180-188. DOI: 10.1061/(ASCE)07339445(2004)130:2(180)

Schneider S P (1998). Axially loaded concrete filled steel tubes. Journal of Structural Engineering, 124(10), 1125-1138. DOI: 10.1061/(ASCE)07339445(1998)124:10(1125)

Tao Z, Han L H \& Wang Z B (2005). Experimental behavior of stiffened concrete-filled thin-walled hollow steel structural (HSS) stub columns. Journal of Constructional Steel Research, 61(7), 962-983. DOI: 10.1016/j.jcsr.2004.12.003

Tao Z, Uy B, Liao F Y \& Han L H (2011). Nonlinear analysis of concrete-filled square stainless steel stub columns under axial compression. Journal of Constructional Steel Research, 67(11), 1719-1732. DOI: 10.1016/j.jcsr.2011.04.012

Tao Z, Wang Z B \& Yu Q (2013). Finite element modelling of concrete-filled steel stub columns under axial compression. Journal of Constructional Steel Research, 89, 121-131. DOI: 10.1016/j.jcsr.2013.07.001

Uy B (2000). Strength of concrete filled steel box columns incorporating local buckling. Journal of Structural Engineering, 126(3), 341-352. DOI: 10.1061/(ASCE)0733-9445(2000)126:3(341)

Yang Z, Zhang Y, Chen M \& Chen G (2013). Numerical simulation of ultra-strength concrete filled steel columns. Engineering Review, 33(3), 211-217.

Yu Q, Tao Z \& Wu Y X (2008). Experimental behavior of high performance concrete-filled steel tubular columns. Thin-Walled Structures, 46(4), 362-370. DOI: $10.1016 /$ j.tws.2007.10.001

Zhao L, Cao W, Guo H, Zhao Y, Song Y \& Yang Z (2018). Experimental and numerical analysis of large scale circular concrete-filled steel tubular columns with various constructural measures under high axial load ratios. Applied Sciences, 8(10), 1894. DOI: 10.3390/app8101894 